\title{
Farm-based Evaluation of Sustainable Alternative Irrigation Practices
}

\author{
Shamotra Jai Oad \\ Department of Civil Engineering Technology, \\ The Benazir Bhutto Shaheed University of Technology and Skill \\ Development, Khairpur Mir's, Sindh, Pakistan \\ shamotra@bbsutsd.edu.pk
}

Abdul Latif Qureshi

US-Pakistan Center Advanced Studies of water Mehran University of Engineering and Technology, Jamshoro, Sindh, Pakistan alqureshi.uspcasw@faculty.muet.edu.pk

\author{
Imran Ali Channa \\ Professional Structural Engineer, \\ Alliance Consultants Pvt Ltd, \\ Karachi, Sindh Pakistan \\ channaimran99@gmail.com
}

\author{
Hadiqa Maqsood \\ US-Pakistan Center Advanced Studies of Water, \\ Mehran University of Engineering and Technology, \\ Jamshoro, Sindh, Pakistan \\ hadiqamaqsood02@gmail.com \\ Shoaib Ahmed \\ Department of Civil Engineering, \\ NED University of Engineering and Technology, \\ Karachi, Pakistan \\ shbned@gmail.com \\ Muhammad Yousif Ali \\ Department of Civil Engineering Technology \\ The Benazir Bhutto Shaheed University of Technology and Skill \\ Development, Khairpur Mir, Sindh, Pakistan \\ muhammadyousifali@gmail.com
}

\begin{abstract}
Water management is one crucial component of agribusiness and municipal policy. One of the water-oriented dimensions is irrigation. In Pakistan, there is a lack of water system planning and water conservation management. This study is an effort to focus on water conservation and optimum crop yield using cost effective irrigation practices. This study is based on the comparative analysis among four irrigation techniques: flood irrigation (conventional), furrow, alternate furrow, and raised bed on wheat crop in order to decide the most efficient irrigation technique on clay loam soil. The wheat crop was cultivated in Rabi season from November 2015 to March 2018 on a one-acre area of a local farmer of Sajawal district, Sindh. Randomize complete block design (RCBD) method was used to design and allocate 3 irrigation sub-plots. The results show significance $p<0.05$ and the efficiency of conserved water by using the furrow irrigation was $25 \%$, alternate furrow $49 \%$, and raised-bed $31 \%$ in comparison to conventional methods. Furthermore, crop yield indicates that furrow irrigation and raised-bed gave higher yields. The increase in yield was $35 \%$ by using raised-bed technique and $20 \%$ by furrow irrigation whereas by using alternate irrigation it was $15 \%$ in comparison with the conventional method. The soil type is clay loam and saline soil.
\end{abstract}

Keywords-water conservation; raised-bed; wheat; Sujawal; alternate furrow

\section{INTRODUCTION}

Developing countries are focusing on the water scarcity problem in order to secure efficient food production. To secure water resources and have optimum use of water, most countries take measures to conserve these resources and mitigate water shortage problems. Irrigation plays a vital role to food production and enhances the economy of a country [1], while most of the population of Asian countries is engaged in agriculture. There are various studies on performance evaluation of water and soil for integrated systems to attain efficient irrigation practices. There are various types of irrigation systems: border irrigation, furrow irrigation, flood irrigation, sprinkler irrigation, and drip irrigation. Flood and border irrigation are inundating the land. Furrow irrigation comes in different types such as alternate furrow, surge, and raised beds. Sprinkler and drip are mechanized systems employing further water conservation strategies. There are generally three water sources for irrigation: groundwater, surface water, and non-conventional sources such as treated wastewater and desalinated water.

The study area is a farmer in Pakistan. The climate of Pakistan is mostly semi-arid in lower Indus basin making irrigation a vital need for food production. At farm level, most of the irrigation water is lost due to deep percolation and surface runoff. Until it reaches the downstream of the region, some water gets wasted due to leakages and line losses. In the most part of the country, farmers divert water to their farm from passing by canals without being charged. The related irrigation department of State Government has taken steps to manage water resources from any sort of theft, but due to population increase and damages of infrastructures, they are 
not capable of fulfilling the production needs. Therefore, to overcome these issues, highly efficient irrigation systems are utilized such as sprinkler and drip. Since most of the farmers either can't afford mechanical means or are unable to handle these advanced systems, they prefer old fashioned, economical irrigation practices like furrow, surge, alternate irrigation, and raised bed [2].

In Pakistan, there is a lack of water system planning, management and proper system operation and maintenance. Time, quality and financial management are important to achieve optimum economy rate while the agriculture production is based on these factors [3]. Authors in [4] used furrow and raised bed techniques and concluded that by adopting these techniques $16.6 \%$ more yield was achieved and $50 \%$ of the water was conserved. Another comparable experiment was performed on crop physiology in seasons 2002-2003 and 2003-2004 [5] between raised-bed planting, furrow irrigation, and conventional free flood irrigation to ameliorate water use efficiency in winter wheat. Authors evaluated the techniques by designing varying row distances between furrows, raised bed and conventional flood. Authors concluded that by keeping $68 \mathrm{~cm}$ bed to bed distance gave maximum wheat yield as compared with furrow and conventional irrigation. Generally, surface irrigation technique is mostly used $(80.9 \%)$ followed by sprinkler [6]. Another research on the effects of raised bed planting was conducted on irrigated wheat yield, as influenced by using a variety of same crop and row spacing. This research was conducted in northwestern Mexico from 1998 to 2005 to check the performance of farmers on how they intern the solar radiations in the gap and reduce their effects between the beds. They found that low density and less row to row spacing gave more yield and reduced by $10 \%$ the losses in the raised-bed system [7]. A similar study focusing on water conservation and crop yield was carried out in [8], where researchers examined the effects of continuous planting, furrow irrigation, and raised bed cropping on water content in soil. The research concluded that deficit irrigation system on furrow cropping gives the best yield in north China. Authors in [9] designed a framework for assessing technology and management options to reduce water losses. They suggested that a framework is needed in adopting alternative irrigation practices and appropriate management techniques that will reduce water shortage. The wheat crop yield and water use efficiency in sandy loam soil can be improved by using conventional tillage practices [10]. By using the furrow planting technique for wheat crop in loamy soil the yield of wheat enlarged [11]. A study on Indo Gangetic basin was done to improve water conservation efficiency [12]. Authors depicted that Indo Genetic countries give less crop yield than the potential, due to lack of water resource management. A field experiment was conducted in the Tandojam region of Pakistan on okra, by using an alternate irrigation practice for water conservation in [13]. It was a comparison between alternative furrow irrigation with conventional irrigation practices. In [14], it was concluded that by using alternative furrow irrigation, crop yield was decreased only to the negligible amount of $7.3 \%$, but crop water productivity was higher with water conservation. Ridged furrow irrigation system extracted optimum moisture from soil and achieved more yield $(66.1 \%$ and $50.4 \%)$ as compared to free flood and mini ditch irrigation practices [15]. As compared to the free flood practice, drip irrigation and furrow irrigation methods gave more yield and water use efficiency (WUE) for chili pepper crop as compared to basin irrigation method. In Afghanistan, farmers prefer furrow irrigation over drip irrigation because it is more economical and easy to maintain [16]. Authors in [17] used furrow and raised bed techniques and concluded that by adopting these techniques $16.6 \%$ more yield was achieved and $50 \%$ of the water was conserved. According to multi criteria analysis, alternative irrigation methods are more suitable for water saving and normal crop yield is obtained [18]. Authors in [19] designed a framework for assessing technology and management options to reduce water losses. They suggested that a framework is needed in adopting alternative irrigation practices and appropriate management techniques that will reduce water shortage. Authors in [20] did a study on crop water productivity, reviewing 84 articles and concluded that minimum wheat crop water productivity range is $0.6-1.7 \mathrm{~kg} / \mathrm{m}^{3}$

\section{MATERIALS AND METHODS}

\section{A. Study Area and Crop}

The wheat crop was cultivated in a local farm in the village Ghullam Shah, district Sujawal, Sindh, Pakistan. It is located at latitude and longitude of $24^{\circ} 29^{\prime} 03^{\prime \prime}$ and $68^{\circ} 12^{\prime} 41^{\prime \prime}$. The highest temperature observed was $41^{\circ} \mathrm{C}$ and the lowest was below $19^{\circ} \mathrm{C}$, while the average annual rainfall is $48 \mathrm{~mm}$. The most cultivated crops are wheat, cotton, sugarcane, rice and mustard. The methodology of this study is focued on field-based analysis for water saving, crop yield, and crop water productivity estimations. It also includes soil and water analysis to determine better irrigation scheduling. A field-based experiment was conducted for three seasons on wheat crop cultivated from November 2015 to March 2018 on clay loam soil. In this study the cultivated crop was Rabi season wheat, the root depth of the crop was $110 \mathrm{~cm}$ and the available soil moisture depletion was $50 \%$.

\section{B. Experimental Design}

A one-acre field was divided into four sections with each treatment having three replications. Treatments were Random Complete Block Design (RCBD) system showing different irrigation methods. The adopted irrigation practices are tabulated in Table I, which shows their geometrical properties. The practices are coded as: free flood as T1, furrow as T2, alternate furrow as T3, and raised bed as T4. Moreover, these irrigation practices are divided into a total of 12 blocks, each block having $23.247 \mathrm{~m}$ length, $14.33 \mathrm{~m}$ width and an area of $333.11 \mathrm{~m}^{2}$.

\section{Irrigation and Fertilization Process}

The equipment installed at the field station was cut throat flume and tensiometers. These were determining the crop water requirements at specific times. The field was irrigated by giving soaking dose and the seeds were sowed manually with hand drill when soil was in full moist condition. Fifty $\mathrm{kg}$ of wheat seed were applied along with $50 \mathrm{~kg}$ of diammonium phosphate fertilizer $\left(\left(\mathrm{NH}_{4}\right) 2 \mathrm{HPO}_{4}\right)$ at the time of sowing and two bags of urea. The nitrogen fertilizer is more suitable compared to potassium $(\mathrm{K})$ and phosphorous $(\mathrm{P})$, due to its 
ability to dissolve quickly in soil while it cannot contaminate ground water [9]. NPKs were applied in the form of urea, diammonium phosphate fertilizer and sulfate of potash. All P, $\mathrm{K}$ with half $\mathrm{N}$ were applied during the land preparation. The remaining half $\mathrm{N}$ was split applied with $2 \mathrm{nd}$, 3rd and 4th irrigations. The crop was harvested on March 2018.

TABLE I. GEOMETRY OF THE EXPERIMENTAL AREA

\begin{tabular}{|c|c|c|c|c|c|c|c|}
\hline $\begin{array}{l}\dot{z} \\
\dot{\bar{t}}\end{array}$ & 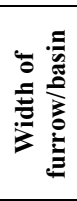 & 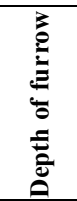 & $\begin{array}{l}0 \\
\dot{0} \\
\dot{0} \\
\dot{0} \\
\dot{0} \\
\dot{0}\end{array}$ & $\begin{array}{l}\frac{n}{d} \\
\frac{\tilde{g}}{0} \\
\dot{8}\end{array}$ & 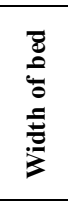 & 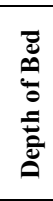 & 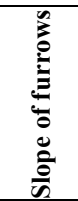 \\
\hline T1 & 14.33 & - & - & - & - & - & - \\
\hline $\mathrm{T} 2$ & & & & & & \multirow{3}{*}{0.31} & \multirow{3}{*}{0.005} \\
\hline T3 & 0.304 & 0.304 & 23 & 23 & 0.305 & & \\
\hline T4 & 0.38 & 0.372 & 15 & 14 & 0.610 & & \\
\hline
\end{tabular}

\section{Sampling and Analysis}

Water samples were collected for quality analysis. The tests consisted of physical and chemical measurements. Before determining the physicochemical parameters, all the equipment was calibrated using distilled water. Regarding soil, a total of 72 disturbed soil samples were collected using an auger hole at different depths of $0-15 \mathrm{~cm}, 15-30 \mathrm{~cm}, 30-45 \mathrm{~cm}, 45-60 \mathrm{~cm}, 60-$ $75 \mathrm{~cm}$ and $75-90 \mathrm{~cm}$ to determine soil texture, bulk density and other parameters. Water and soil analyses were performed at the Drainage and Reclamation Institute of Pakistan (DRIP), Pakistan Council of Research in Water Resources (PCRWR), Tandojam, Pakistan.

\section{E. Irrigation Scheduling}

The irrigation of wheat crop under furrow, alternate furrow, raised bed irrigation and conventional practice was applied at 21-25 day intervals. The irrigation of wheat crop underneath conventional irrigation technique was based on the farmer's practices. Equation (1) was used to determine crop water requirement [1]:

$$
R=\frac{(F . C-M . C)}{100} \times B \times D
$$

where $R=$ water requirement, $F . C=$ field capacity $(\%)$, $M . C=$ moisture content $(\%), B=$ bulk density $\left(\mathrm{g} / \mathrm{cm}^{3}\right)$, and $D=$ depth of root zone $(\mathrm{cm})$.

\section{F. Irrigation Application}

The irrigation application of each treatment was calculated to obtain the irrigation efficiencies and water productivity.

\section{G. Crop Water Requirement}

Crop water requirement was found by:

$$
C W R=E T_{o} \times K C
$$

where $E T_{o}$ is the evapotranspiration and $K c$ is crop coefficient.

\section{H. Crop Water Productivity}

Crop water productivity (CWP) of raised-bed and conventional irrigation systems was calculated by [1]:

$$
C W P=\frac{Y}{W R}
$$

where $C W P=$ water use efficiency $\left(\mathrm{kg} / \mathrm{m}^{3}\right), Y=$ yield of crop $\left(\mathrm{kg} \cdot \mathrm{ha}^{-1}\right), W R=$ total water consumed $\left(\mathrm{m}^{3} \mathrm{ha}^{-1}\right)$.

\section{Water Saving}

The water saving for wheat crop over the conventional irrigation system was calculated as:

$$
W S(\%)=\frac{W a-W b}{W a}
$$

where, $W S=$ water saving (\%), $W_{a}=$ maximum total water used in conventional irrigation system in water application practice $\left(\mathrm{m}^{3}\right)$, and $W_{b}=$ minimum total water used in the irrigation system in water application practice $\left(\mathrm{m}^{3}\right)$.

\section{RESULTS AND DISCUSSION}

The results show that the soil was quite saline and local farmers did not have any idea about economical and efficient irrigation practices, because mostly they are uneducated and lack technical skills, therefore they adopt traditional practices. The water analysis gave the results shown in Table II. Vanal water was non-saline and non-sodic. The mean $\mathrm{pH}$ value of water was $8.4, E c$ was $1080 \mu \mathrm{Scm}^{-1}$, TDS was $681.8 \mathrm{ppm}$, chloride 5.6, the presence of sodium in water source was 3.2, and the sodium absorption ratio was 3.2. From the experimental results it is clear that the quality of the available water is marginally useable and not too good.

TABLE II. WATER SAMPLE CHARACTERISTICS

\begin{tabular}{|c|c|c|c|c|}
\hline Sample No. & ECw $\left(\boldsymbol{\mu S} \mathbf{~ c m}^{-1}\right)$ & pH & TDS (ppm) & SAR \\
\hline 1 & 1051 & 8.2 & 683.15 & 3.2 \\
\hline 2 & 1100 & 7.7 & 700 & 3.5 \\
\hline 3 & 1085 & 8.1 & 670 & 3.4 \\
\hline 4 & 1095 & 8.5 & 680 & 3.1 \\
\hline 5 & 1065 & 8.2 & 675 & 3.0 \\
\hline
\end{tabular}

Soil sample analysis was done before sowing and after harvesting. Its purpose was to know soil condition, texture and salinity status. The results concluded that the soil condition was more saline before sowing and after harvesting it was less due to evapotranspiration and soil texture changes from depth to depth. The mean value of soil texture was clay loam (Table III).

TABLE III. SOIL CHARACTERISTICS

\begin{tabular}{|c|c|c|c|c|c|}
\hline \multirow{2}{*}{ Parameters } & \multirow{2}{*}{ Unit } & \multicolumn{4}{|c|}{ Results } \\
\cline { 3 - 6 } & & $\mathbf{T}_{\mathbf{1}}$ & $\mathbf{T}_{\mathbf{2}}$ & $\mathbf{T}_{\mathbf{3}}$ & $\mathbf{T}_{\mathbf{4}}$ \\
\hline $\mathbf{E c}$ & $\left(\mu \mathrm{S} \mathrm{cm}^{-1}\right)$ & 996 & 867 & 680 & 920 \\
\hline $\mathbf{p H}$ & - & 8.35 & 8.4 & 8.1 & 8.2 \\
\hline $\mathbf{S A R}$ & - & 3.4 & 3.1 & 3.5 & 3.8 \\
\hline $\mathbf{E S P}$ & $\%$ & 3.9 & 3.4 & 3.7 & 3.8 \\
\hline $\mathbf{C O}_{\mathbf{3}}$ & $\mathrm{me} / \mathrm{L}$ & 0.03 & $\mathrm{Nil}$ & $\mathrm{Nil}$ & 0.02 \\
\hline $\mathbf{H C O}_{\mathbf{3}}$ & $\mathrm{me} / \mathrm{L}$ & 2 & 2.7 & 3 & 1.6 \\
\hline $\mathbf{C l}$ & $\mathrm{me} / \mathrm{L}$ & 3 & 5 & 4 & 3.4 \\
\hline $\mathbf{C a}+\mathbf{M g}$ & $\mathrm{me} / \mathrm{L}$ & 3.6 & 5 & 4.10 & 5.5 \\
\hline $\mathbf{N a}$ & - & 3.2 & 6 & 4.20 & 3.35 \\
\hline $\mathbf{S O}_{\mathbf{4}}$ & $\mathrm{me} / \mathrm{L}$ & 1.7 & 3.2 & 3.3 & 2.2 \\
\hline
\end{tabular}

Table IV shows the water savings per irrigation method. Figure 1 shows the field experiment of the applied methods of irrigation. The difference in water application, seepage, and crop growth can be seen. Crop water productivity and increase in yield is illustrated in Table V. The results show that furrow 
irrigation yield production was $5928 \mathrm{~kg}$, for alternate it was $5681.988 \mathrm{~kg}$, for raised-bed it was $6669 \mathrm{~kg}$, and conventional gave $4940 \mathrm{~kg}$. The total day number from sowing to harvest was 123 from November to March. The CWR of the wheat crop was $314 \mathrm{~mm}$, determined by using ETo and $K c$ values as illustrated in Table VI.

TABLE IV. WATER SAVINGS AND COMPARISON TO CONVENTIONAL METHOD

\begin{tabular}{|c|c|c|}
\hline Method & $\begin{array}{c}\text { Consumption of water for } \\
\left.\text { wheat crop } \mathbf{~ ( ~}^{\mathbf{3}} \mathbf{h e c}^{-\mathbf{1}}\right)\end{array}$ & Water saving (\%) \\
\hline $\mathrm{T} 1$ & 4431.18 & - \\
\hline $\mathrm{T} 2$ & 3328.572 & $25 \%$ \\
\hline $\mathrm{T} 3$ & 2297.0 & $49 \%$ \\
\hline $\mathrm{T} 4$ & 3076.63 & $31 \%$ \\
\hline
\end{tabular}

TABLE V. CROP WATER PRODUCTIVITY AND INCREASE IN YIELD COMPARISON WITH CONVENTIONAL IRRIGATION

\begin{tabular}{|c|c|c|}
\hline Method & $\begin{array}{c}\text { Crop water productivity } \\
\text { (mean) } \mathbf{( k g ~ m}^{-3} \text { ) }\end{array}$ & Increase in yield (\%) \\
\hline$T_{1}$ & 1.011 & - \\
\hline$T_{2}$ & 2.14 & 20.0 \\
\hline$T_{3}$ & 3 & 15.0 \\
\hline$T_{4}$ & 1.75 & 35.0 \\
\hline
\end{tabular}

TABLE VI. WHEAT CROP WATER REQUIREMENTS

\begin{tabular}{|c|c|c|}
\hline Period & $\mathbf{E t}_{\mathbf{0}}$ & $\mathbf{K}_{\mathbf{c}}$ \\
\hline November & 4.83 & 0.35 \\
\hline December & 4.0 & 0.75 \\
\hline January & 3.3 & 1.0 \\
\hline February & 4.62 & 0.85 \\
\hline March & 5.33 & 0.65 \\
\hline Average & 3.55 & 0.72 \\
\hline
\end{tabular}

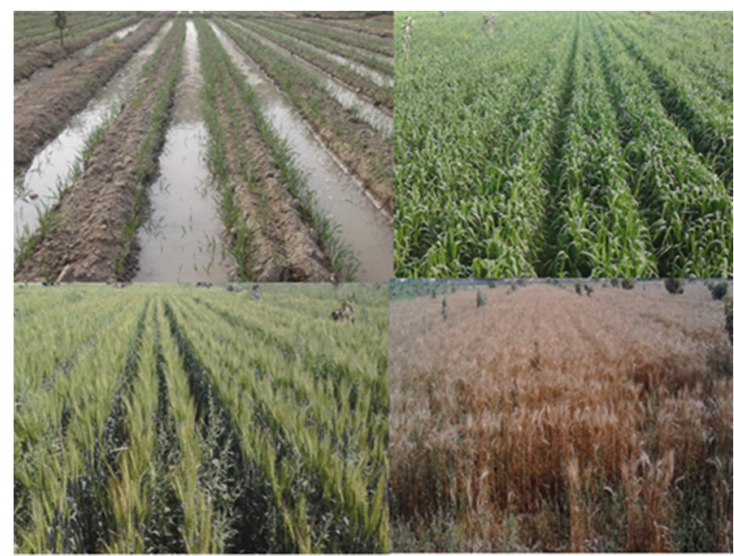

Fig. 1. Growing stages of wheat crop

The study area map was digitized by the Arc Geographical Information System (Arc-GIS). Crop water requirements were calculated with the help of the evapotranspiration data. The monthly data of evapotranspiration of 2015-2018 were collected from the metrological department of Karachi, they can also be downloaded from the USGS website. Economic analysis was also done. It showed that use of furrow irrigation system is more profitable. The social aspect was also taken into consideration. It was the first time where a local farmer was convinced on the application of furrows, alternative, and raised bed irrigation practices, making it a challenge. The main issue was system monitoring and understanding the methods and their significance. The will of farmers is to be appreciated, however there is a dire need of awareness and acceptability toward non-conventional systems. Figure 2 shows the comparative irrigation application under various irrigation modes. Graphical representation shows maximum quantity of water about $4000 \mathrm{~m}^{3} / \mathrm{hc}$. The alternate furrow irrigation system utilized $51.83 \%$ less water as compared to free flood, and furrow and raised-bad irrigation systems utilized equal quantities of water. Figure 3 depicts the comparative crop yield for various irrigation practices. Raised-bed achieves maximum yield of wheat crop as compared to other irrigation systems.

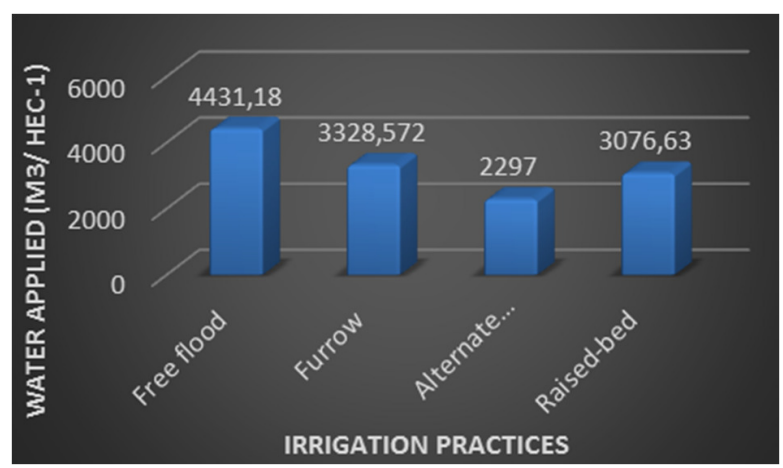

Fig. 2. Water applied to wheat crop under alternate irrigation practices in comparison with free flood

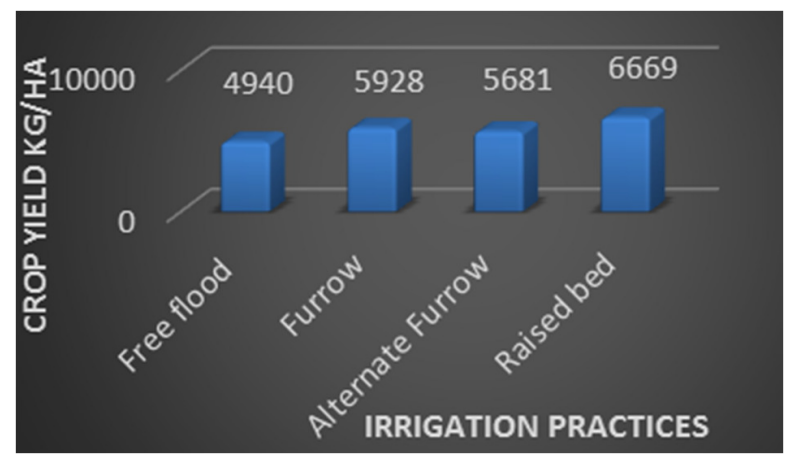

Fig. 3. Comparative analysis of crop yield

Statistical analysis was performed to justify the results of yield and water applied by using ANOVA testing. An analysis of variance for significance $\mathrm{p}<0.05$ was used to determine differences between means. The ANOVA test results are illustrated in Tables VII and VIII. Note: The results show that there is a variance between irrigation practices and between groups the ANOVA gives significant result values, i.e. 0.0004, which is less than 0.01 and $F_{\text {critical }}$ is less than $F$, also showing significance between values.

TABLE VII. ANOVA RESULTS

\begin{tabular}{|c|c|c|c|c|}
\hline Method & Conventional & Furrow & Alternate furrow & Raised-bed \\
\hline Sum & 179.4 & 134.7 & 93 & 124.56 \\
\hline Average & 29.9 & 22.46 & 15.5 & 20.76 \\
\hline Variance & 0.156 & 14.27 & 52.62 & 21.35 \\
\hline F & \multicolumn{4}{|c|}{9.62} \\
\hline p-value & \multicolumn{4}{|c|}{0.000387} \\
\hline $\mathrm{F}_{\text {critical }}$ & \multicolumn{4}{|c|}{3098} \\
\hline
\end{tabular}


TABLE VIII. ANOVA RESULTS FOR CROP YIELD

\begin{tabular}{|c|c|c|c|c|}
\hline Method & Conventional & Furrow & Alternate furrow & Raised-bed \\
\hline Sum & 500 & 600 & 575 & 675 \\
\hline Average & 166.7 & 200 & 191.7 & 225 \\
\hline Variance & 2.33 & 100 & 10.57 & 9.0 \\
\hline F & \multicolumn{3}{|c|}{0,000009} \\
\hline p-value & \multicolumn{5}{|c|}{4.07} \\
\hline F $_{\text {critical }}$ & \multicolumn{5}{|c}{} \\
\hline
\end{tabular}

\section{CONCLUSION}

The area of study for this research is composed of clay loam receiving canal water that is marginally saline but still good for irrigation. The quality of water was marginally useable and its dry bulk density was $1.35 \mathrm{gm} \cdot \mathrm{cm}^{-3}$, the field capacity was $26.5 \%$, and the infiltration rate was $0.18 \mathrm{~cm} \cdot \mathrm{hr}^{-1}$. Out of the four irrigation practices, on-farm based analysis showed that alternate furrow technique gave most water saving but not enough yield, whereas raised bed method enhanced $26 \%$ of yield and conserved $31 \%$ more water compared to conventional flood irrigation. ANOVA provides evidence to the results. This concludes that raised bed is the most effective irrigation practice.

\section{ACKNOWLEDGEMENT}

Authors are thankful to the US-Pakistan Center for Advanced Studies in Water, MUET, Jamshoro for the financial support and to the Drainage and Reclamation Institute of Pakistan (DRIP), Pakistan Council of Research Water Resource (PCRWR), Tandojam for the laboratory work.

\section{REFERENCES}

[1] M. M. A. Kaisi, J. F. Shanahan, Irrigation of Winter Wheat, Crop Series, 1999

[2] N. Dabour, "The role of irrigation in food production and agricultural development in the near east region", Journal of Economic Cooperation, Vol. 23, No. 3, pp. 31-70, 2002

[3] A. Darzi-Naftchali, H. Ritzema, "Integrating irrigation and drainage management to sustain agriculture in northern Iran", Vol. 10, No. 6, pp. $1-17,2018$

[4] R. A. Fischer, K. Sayre, I. O. Monasterio, "The effect of raised bed planting on irrigated wheat yield as influenced by variety and row spacing", in: ACIAR Proceedings No. 121, pp. 1-11, Australian Centre for International Agricultural Research, 2005

[5] J. M. Goncalves, A. P. Muga, M. G. Horst, L. S. Pereira, "Furrow irrigation design with multicriteria analysis", Biosystems Engineering, Vol. 109, No. 4, pp. 266-275, 2011

[6] E. A. Holzapfel, M. A. Marino, J. Chavez-Morales, "Procedure to select an optimum irrigation method", Journal of Irrigation and Drainage Engineering, Vol. 111, No. 4, pp. 319-329, 1985

[7] M. L. Jat, R. Gupta, Y. S. Saharawat, R. Khosla, "Layering precision land leveling and furrow irrigated raised bed planting: Productivity and input use efficiency of irrigated bread wheat in Indo-Gangetic plains", American Journal of Plant Sciences, Vol. 2, No. 4, pp. 578-588, 2011

[8] D. Labadarios, Z. J. Mchiza, N. P. Steyn, G. Gericke, E. M. Maunder, Y. D. Davids, W. A. Parker, "Food security in South Africa: A review of national surveys", Bulletin of the World Health Organization, Vol. 89, No. 12, pp. 891-899, 2011

[9] D. K. Majumdar, Irrigation Water Management Principles and Practices, Prentice Hall of India, 2010

[10] G. Mishra, H. S. Kushwaha, "Winter wheat yield and soil physical properties responses to different tillage and irrigation", European Journal of Biological Research, Vol. 6, No. 1, pp. 56-63, 2016
[11] L. Quanqi, Z. Xunbo, C. Yuhai, Y. Songlie, "Water consumption characteristics of winter wheat grown using different planting patterns and deficit irrigation regime", Agricultural Water Management, Vol. 105 , pp. 8-12, 2012

[12] B. R. Sharma, U. Amarasinghe, C. Xueliang, "Assessing and Improving Water Productivity in Conservation Agriculture Systems in the IndusGangetic Basin", 4th World Congress on Conservation AgricultureInnovations for Improving efficiency, Equity and Environment, New Delhi, India, February 4-7, 2009

[13] A. A. Siyal, A. S. Mashori, K. L. Bristow, M. T. V. Genuchten, "Alternate furrow irrigation can radically improve water productivity of okra", Agricultural Water Management, Vol. 173, pp. 55-60, 2016

[14] K. B. Soomro, H. A. Sahito, J. A. Rind, B. Mal, S. H. Kaleri, "Effect of marginal quality water on okra, abelmoschus esculentus I. Yield under drip irrigation system", Global Advanced Research Journal of Engineering, Technolology and Innovation, Vol. 1, No. 5, pp. 103-112, 2012

[15] C. Sun, D. Feng, Z. Mi, C. Li, J. Zhang, Y. Gao, J. Sun, "Impacts of ridge-furrow planting on salt stress and cotton yield under drip irrigation”, Water, Vol. 9, No. 1, pp. 49, 2017

[16] F. A. Ward, A. Michelsen, "The economic value of water in agriculture: Concepts and policy applications", Water Policy, Vol. 4, No. 5, pp. 423446, 2002

[17] E .A. Waraich, R. Ahmad, Saifullah, S. Ahmad, "Raised bed planting in wheat (Triticum aestivum L.) in semi-arid zone", Iranian Journal of Plant Physiology, Vol. 1, No. 2, pp. 73-84, 2010

[18] S. A. Walters, A. K. Jha, "Sustaining chili pepper production in Afghanistan through better irrigation practices and management", Agriculture, Vol. 6, No. 62, pp. 1-10, 2016

[19] D. Zingaro, I. Portoghese, G. Giannoccaro, "Modelling crop pattern changes and water resources exploitation: A case study", Water, Vol. 9, No. 9 , pp. 685,2017

[20] S. J. Zwart, W. G. M. Bastiaanssen, "Review of measured crop water productivity values for irrigated wheat, rice, cotton and maize", Agricultural Water Management, Vol. 69, No. 2, pp. 115-133, 2004 